\title{
Women Equality In Labour Market: A Myth Or A Reality? The Case Of Women PR Managers
}

Zoe Ventoura, (E-mail: ventura@aueb.gr), Athens University of Economics and Business, Greece Afroditi Neokosmidi, National Organization of Medicines, Greece Anastasios Theofilou, Athens University of Economics and Business, Greece Pavlos Ioannidis, National Technical University of Athens, Greece

\begin{abstract}
Whether or not women's presence in the labour market has improved the last decades is under investigation. This study examines the historical evolution of gender equality, the labour characteristics and the main reasons of gender inequality in Greece. In order to validate the study a research is undertaken using a sample of 258 PR managers. The purpose of the research is to examine whether gender is responsible for the difference in the given answers of the $P R$ managers. The analysis reached interesting conclusions concerning the issues that need to be reevaluated by society in order to improve women's position in society and business.
\end{abstract}

\subsection{INTRODUCTION}

Tomen's presence in the labour market has improved the last decades. However this improvement is rather visible when examining only developed countries, while the rapidity of the improvement consist a matter of deeper investigation. The rapidity of women's improvement in professional hierarchy depends on the cultural beliefs of the particular society towards women's relative position. (Wirh 2001).

The fact, that many women having the same education and sharing the same ambitions with their men colleagues find themselves facing a "glass ceiling", reveals the existence of gender inequality (Powell 1999). Only the $25 \%$ of women that work in either Public or Private Sector will reach high managerial positions. In secondary education, which is a Sector that women consist the majority of the working population, only $9 \%$ become Principals. As for women who have studied scientific and technological disciplines the percentage of those who climb up the hierarchical ladder are even lower. The use of the term "glass ceiling" was used for the first time from journalists of the Wall Street Journal in order to describe the fictional barriers that stop or retard women's hierarchical upward path.

The patriarchal Greek society brings women in a rather disadvantageous position in the workplace and at home, revealing that the country has a long way to cover in order to achieve gender equality (Athena Petraki Kottis and Zoe Ventoura Neokosmidi 2000).

The main aim of this study is to present women's position nowadays as a part of the economic and business development in Greece while emphasizing the case of the role and profile of women working as Public Relations Managers.

The paper is organized as follows. Section two includes a historical evolution and the Country's legislation for gender equality. The next Section the characteristics of the labour force. Section four explains the reasons for gender inequality. Section five exhibits the comparison between women and men Public Relations managers. Finally, some concluding remarks are presented in the last Section. 


\subsection{HISTORICAL EVOLUTION AND COUNTRY LEGISLATION FOR GENDER EQUALITY}

Surely the development of a Country, of a society or even of society members, such as women, depends on education. The first steps to promote gender equality were taken in 1834 when according to country legislation both genders could attend elementary school. Nevertheless students were divided into separate schools according to their gender while the level of education provided to women was lower than that of men. Women were allowed access to secondary education just after 1840 but due to high tuition fees and insufficient level of teaching the educational system lacked in promoting gender equality.

The year 1861 may be considered the first year which in a sense promoted equality in labour market since the profession of "teacher" for women is legitimized by Royal Decree. After 1861 the road was opened for 1914 which was the first year that women were allowed to teach in secondary education. Nevertheless according to a survey conducted in 1930 a $70 \%$ of women over 30 years old were found illiterate.

A law of 1952 is considered crucial for gender equality giving the right to women to vote and be voted, while the Constitution of 1975 made it clear that all Greeks, men and women, were equal for the law.

In 1979 Greece legitimizes the UN Treaty against sexism, while in 1981 being a full member state of the European Union the Country follows all the instructions concerning gender equality. Greece has also legitimized International Labour Convention concerning labour equality in all fields (wages, value of work)

Despite the increase of women attending higher education the last decades, women still work on traditional fields and do not move into higher positions. The Research Center for Gender Equality (RCGE) conducted a very interesting survey concerning higher education for schoolar year 2000-2001 on senior High School students in order to examine their preferences according to their gender between the three available fields of studies after graduating from High School. From the survey it was observed that among those who preferred to continue their studies in the field of:

1. mental philosophy, the $22 \%$ were men and $78 \%$ were women

2. technological studies, the $52 \%$ were men and $48 \%$ were women

3. scientific disciplines, the $65 \%$ were men and $35 \%$ were women $\mathrm{t}$

The findings of the survey conclude that: a) gender remains a significant factor when choosing field of studies b) men's preference in technological studies and scientific disciplines confirms the traditional social standards c) the small gap between women and men in the field of technological studies is rather factitious since this field includes Biology and Chemistry, which are two disciplines that were traditionally chosen mainly by women.

\subsection{LABOUR FORCE CHARACTERISTICS}

According to Petraki-Kottis (1990) the evolution to women's status in labour market is unworthy of remarks in comparison with the evolution made in other countries or with the evolution that one might have expected. Nowadays the situation is approximately the same.

On 2005 women consisted the $51.4 \%$ of the total population while men consisted the $48.6 \%$. Nevertheless for the employed population women amount the $40.8 \%$, while the corresponding figure of men is $59.2 \%$.

Diagram 1 shows women's position in labour market between 2001 and 2005. 
Diagram 1

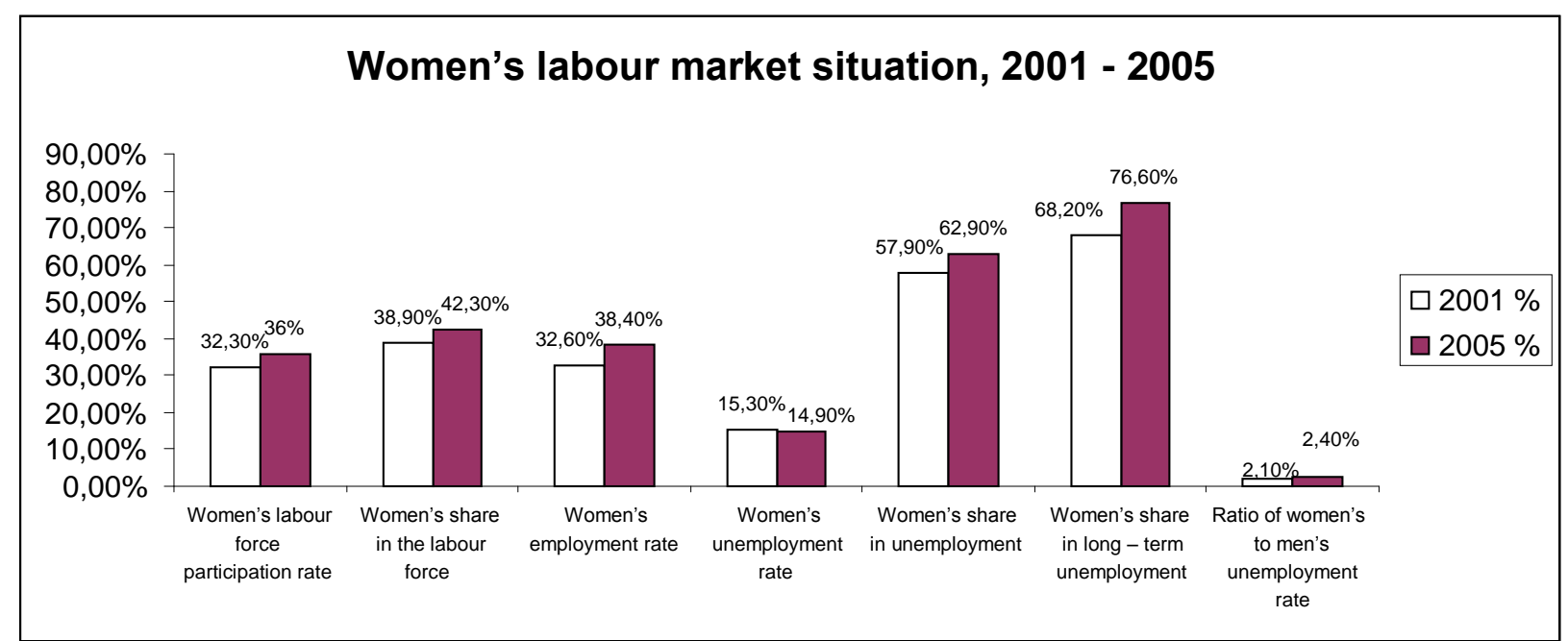

Source: Unpublished data of National Statistical Service of Greece 2005

The comparison of the examined years demonstrate that there is a slight increase in women's participation in the labour force and in employment despite the fact that women's share in unemployment has risen from 2001 to 2005. Furthermore long-term unemployment seems to have a worse effect on women than in men since it has risen from $68.2 \%$ on 2001 to $76.6 \%$ on 2005 , while women's ratio to men's unemployment rate is 2.5 times higher. According to Eurostat, Greece has the third largest percentage of unemployment in the EU-25 with $14.9 \%$ following Slovakia (17.3\%) and Poland (19.2\%).

As illustrated in Diagram 2 women's participation in high levels of hierarchy is rather low, since the $25.7 \%$ of women working as employees and are self-employed, falls to $24.6 \%$ when excluding from the examination the self-employed.

\section{Diagram 2}

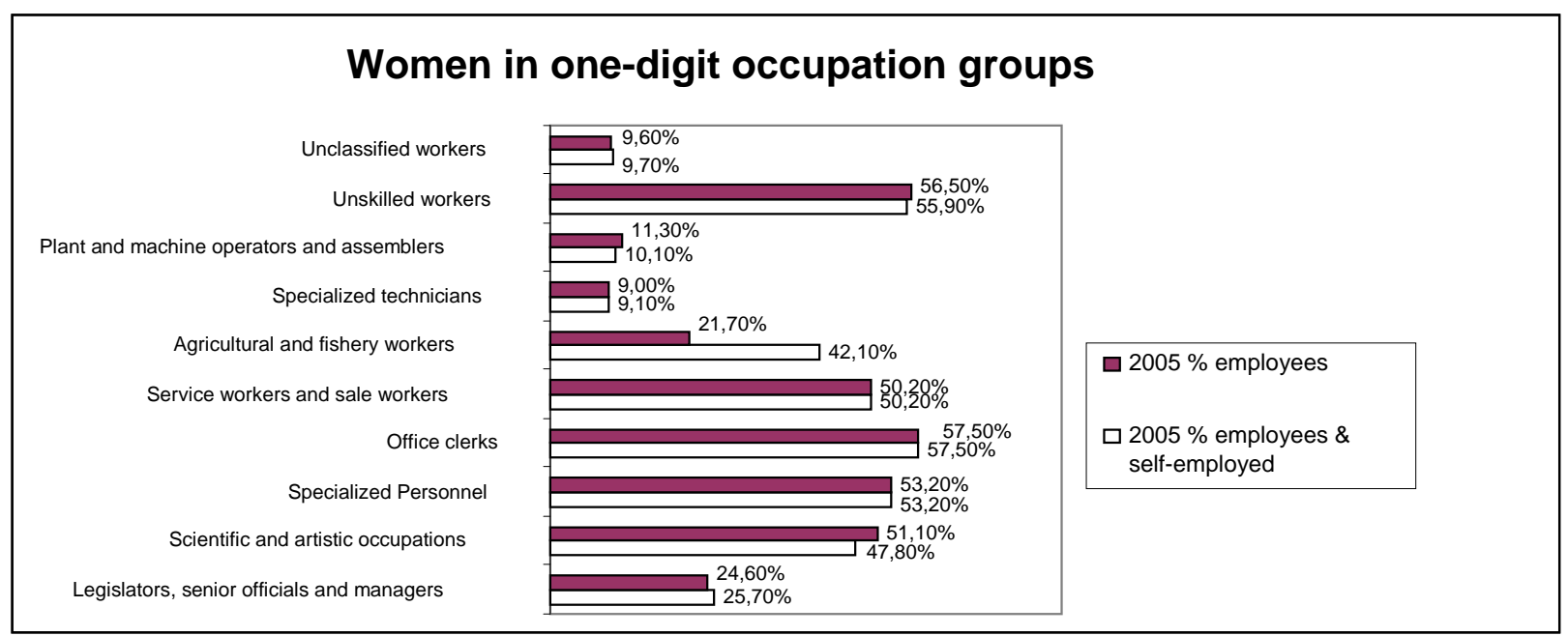

Source: Unpublished data of National Statistical Service of Greece 2005 
It can be observed that women are occupied in a percentage over $50 \%$ as specialized personnel, office clerks, service workers /sale workers and unskilled workers.

The high percentage of women choosing the specific occupations is explained when one takes into consideration that the women attend University study scientific and technical disciplines. Moreover it can be comented that women avoid working in what is considered as "men occupations", such as plant and machine operators and assemblers or specialized technicians.

In order to have an overview of labour characteristics we must also take into consideration the wage gap between men and women. While men on 2001 are paid 1028 euros, 1506 euros and 1686 euros when working respectively in the Primary Field, the Secondary Field and the Tertiary Field women earn for the same year, 873 euros in the Primary Field, 1217 euros in the Secondary Field and 1359 euros in the Tertiary Field. The wage gap remains approximately the same on 2005. Men earn 1353 euros for the Primary Field, 1942 euros for the Secondary Field and 2178 euros for the Tertiary Field, while women earn respectively 1099 euros, 1640 euros and 1783 euros.

It is obvious that the average monthly labour cost for men is approximately 300 euros higher than that of women.

\subsection{REASONS OF GENDER INEQUALITY}

While examining the reasons of gender inequality we may reach some very interesting findings.

We start with the fact that the overwhelming majority of all administrative places are taken by men and creates considerable obstacles to women's professional evolution to higher positions. In addition men usually do not trust women in high positions of hierarchy.

Gender inequality has also its routes to prejudices which exist in Greek society and especially in Greek countryside, where women actually were tended to be convinced that they do not have the skills to compete men or even accomplish the same works as men. In order to fight these prejudices the EU encourages the creation of women's agricultural associations so that women may acquire knowledge over entrepreneurship. Gender equality starts from the family. The structure and the old patriarchal perceptions have given women a secondary role in society and in business. The household's work concerns, or at least should concern, both men and women. Equality in labour market without affecting the balance of sharing works and conditions within the family is inevitable. It is considered that a woman's income couldn't be the main income or of course the only income for the family. In reality it seems that women undertake the role of a goodwife, leaving the more significant decisions of the household to men.

This study confirms that the prejudices of the past, the educational system and family traditions enforce a culture and a way of thinking according to which women are suitable for housewives, and for particular jobs and for low rank hierarchical positions. The educational system has huge responsibility for this behavior and the perceptions of this kind (Barrett 1980, Schmuch 1987, Acker 1989).

The EU, and consequently Greece, has undertaken a number of policies facilitating women who are also mothers to fulfill their working activities through part-time job. Nevertheless, as convenient as this may seems it excludes women to participate equally with men in the labour market. It seems that the EU in contrast with the United States presumes that there is a linkage between productivity and physical presence in the place of work.

For the needs of this study the investigation will go further to examine the case of women in the profession of PR managers. The purpose of choosing the specific sector has to do with the fact that women in the PR sector are the majority in comparison with men, while the aim of the investigation is to observe the importance of gender in decision making. 


\subsection{COMPARISON BETWEEN WOMEN AND MEN PR MANAGERS}

For the purposes of this study a research was conducted in Greece with 258 PR managers, from whom 151 were women and 107 were men working for public and private firms.

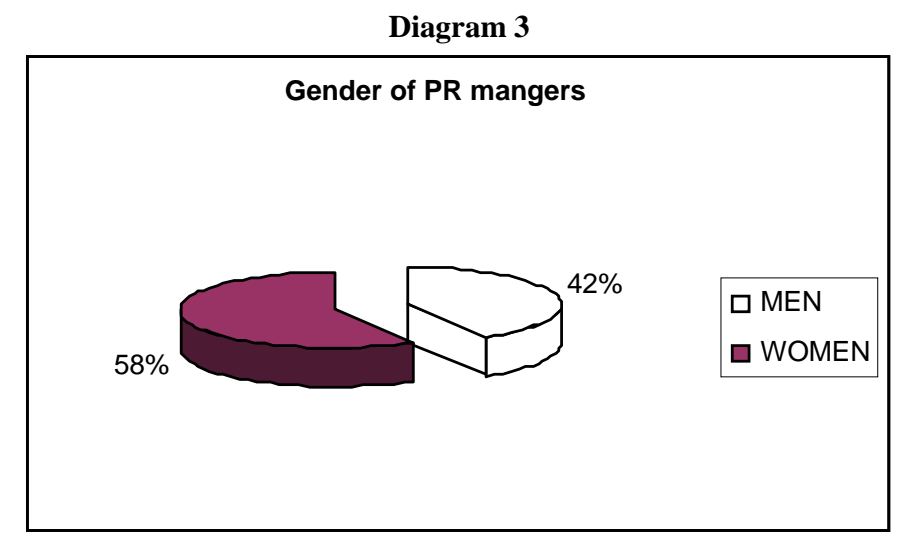

The $47,7 \%$ of women PR managers are between 26 and 35 years, while the majority of men PR managers at a percentage of $42.1 \%$, age between 36 and 45 years old.

Concerning the education level of the PR managers, on one hand the $40.4 \%$ of women PR managers are University graduates and $21.2 \%$ has also Postgraduate studies, while on the other hand a $44.9 \%$ of men PR managers are University graduates and $14 \%$ has a Postgraduate degree.

The PR managers were asked to point out the most important problems that they face when practicing their profession. The examined problems which are faced by PR managers are summarized to the following categories: 1. "management and time distribution" 2. "bad internal relations" 3. "absence of patterns and procedures in the firm" 4. "pressure they receive from the internal and external environment of the firm" 5. "relations with other departments" 6. "lack of authority" 7. "too much association with internal colleagues" 8. "too much association with external cooperators" 9. "bad relations with external co-operators", 10. "bureaucracy", 11. "lack of education".

Both men and women practitioners agreed and ranked first as the most important problem for the profession of PR manager the "absence of patterns and procedures in the firm".

Women PR managers in contrast consider that most important problems following the first above are:

1. "management and time distribution"

2. "pressure they receive from the internal and external environment of the firm"

3. "bad internal relations"

In the contrary for men PR managers the most important problems following the first mentioned in the previous paragraph are:

1. "bad internal relations"

2. "relations with other departments"

3. "management and time distribution"

It seems that women face problems with managerial issues, while men with relational. 
The sample of 258 PR managers was asked their perception whether they decide alone or have to consult others in order to reach strategic and everyday decisions.

When asked if they take full responsibility and decide on their own for issues of strategic matter the $57 \%$ of women managers answered that they decide for the $50 \%$ of the issues on their own (Table 1). Respectively the $67.3 \%$ of men managers answered that they decide for the $50 \%$ of the issues on their own (Table 2).

\begin{tabular}{|c|c|c|}
\hline \multicolumn{2}{|c|}{ Table 1 } \\
Women PR managers \\
\hline $\begin{array}{c}\text { Percent of decision making for } \\
\text { strategic issues }\end{array}$ & Number of managers & Percentage \\
\hline $0 \%$ & 26 & 57,0 \\
\hline $50 \%$ & 86 & 15,9 \\
\hline $100 \%$ & 24 & 90,1 \\
\hline Answered & 136 & 9,9 \\
\hline Missing & 15 & 100 \\
\hline Total & 151 & \\
\hline
\end{tabular}

\begin{tabular}{|c|c|c|}
\hline \multicolumn{2}{|c|}{$\begin{array}{c}\text { Table 2 } \\
\text { Men PR managers }\end{array}$} \\
\hline $\begin{array}{c}\text { Percent of decision making for } \\
\text { strategic issues }\end{array}$ & Number of managers & Percentage \\
\hline $0 \%$ & 6 & 5,6 \\
\hline $50 \%$ & 72 & 67,3 \\
\hline $100 \%$ & 22 & 20,6 \\
\hline Answered & 100 & 93,5 \\
\hline Missing & 7 & 6,5 \\
\hline Total & 107 & 100 \\
\hline
\end{tabular}

Further the PR managers were asked if they take full responsibility and decide on their own for every day issues. The $60.9 \%$ of women managers answered that they decide for the $50 \%$ of the issues on their own (Table 3 ), while for men PR mangers the 56.1\% answered that they decide for the 50\% of the issues on their own (Table 4).

\begin{tabular}{|c|c|c|}
\hline \multicolumn{3}{|c|}{ Table 3 } \\
Women PR managers \\
\hline $\begin{array}{c}\text { Percent of decision making for } \\
\text { everyday issues }\end{array}$ & Number of managers & Percentage \\
\hline $0 \%$ & 9 & 6,0 \\
\hline $50 \%$ & 92 & 60,9 \\
\hline $100 \%$ & 38 & 25,2 \\
\hline Answered & 139 & 92,1 \\
\hline Missing & 12 & 7,9 \\
\hline Total & 151 & 100 \\
\hline
\end{tabular}




\begin{tabular}{|c|c|c|}
\hline \multicolumn{2}{|c|}{$\begin{array}{c}\text { Table 4 } \\
\text { Men PR managers }\end{array}$} & Percentage \\
\hline $\begin{array}{c}\text { Percent of decision making for } \\
\text { everyday issues }\end{array}$ & Number of managers & 0,9 \\
\hline $0 \%$ & 1 & 56,1 \\
\hline $50 \%$ & 60 & 34,6 \\
\hline $100 \%$ & 37 & 91,6 \\
\hline Answered & 98 & 8,4 \\
\hline Missing & 9 & 100 \\
\hline Total & 107 & \\
\hline
\end{tabular}

The survey of PR managers confirms what has been previously written. Women PR managers seem to hesitate when it comes to undertake the responsibility of serious decisions and feel more comfortable when they decide for everyday tasks. With this kind of reactions, which became part of their nature women cannot compete with men in the business world.

\subsection{CONCLUSIONS}

This study has proven that in the case of Greece gender equality is more of a myth than reality, despite the activities and policies undertaken by the country to promote Women Entrepreneurship and Gender Equality.

Greece as a developing country, besides the fact that as a member of the EU has adopted EU policies, has undertaken efforts and has made legislative assessments in order to outlook Gender Inequality and Women Unemployment. Nevertheless, according to evidence from 2005, women may consist the 51,4\% of the total population while men consist the $48,6 \%$, for the employed population though women amount the $40,8 \%$ while the correspondingly figure of men is $59,2 \%$.

Moreover this study has proven that women continue to work in the fields of business that they have traditionally worked for.

Gender inequality owes mainly its existence to the educational system, which drives women to traditional occupations, prejudices of the past and to men who by not trusting them makes it very difficult for them to brake the "glass ceiling".

A survey which was conducted for the purposes of this study on PR managers, a field which the majority of managers are women, certifies the fact that even when women brake the "glass ceiling" and move on to managerial positions hesitate to undertake the responsibility of serious decisions.

This is even clearer since only the $57 \%$ of the women in comparison with the $67,3 \%$ of men answered that they participate actively to the final process of decision making. Furthermore when the respondents were asked about the problems they consider as more important, women differentiate their answers from those given by men revealing the insecurities they feel as managers.

Women since ancient times have played an extremely significant role. It seems that the cultural beliefs of the particular society needs to take more steps forward to accept women not only as unsung heroes but as equal partners in business and society. Surely a number of issues need to be reevaluated by society in order to improve women's position in the future. 


\section{REFERENCES}

1. $\quad$ Acker, S., ed.,(1989), Teachers, Gender and Careers, The Falmer Press, London.

2. Amorin, G., Fulle, I., Gaham-Bouchenmal, N., Gourdet, A. and Logoeiro, C., (1998), Reference Manuel on Equal Opportunities and Gender Dimension in Primary and Secondary Education in the European Union, European Commission, DG XXII

3. Barret, M., (1980), Women's Oppression Today, Verso, London.

4. Catalyst (1999) The 1999 Catalyst Census of Women Corporate Officers and Top Earners, Catalyst, New York

5. Catalyst (2000) The 1999 Catalyst Census of Women Corporate Officers of Canada, Catalyst, New York.

6. Davidson, M.J. and Burke, R.J. (eds), (2000), Women in Management: Current Research Issues Vol. II, Thousand Oaks, CA: Sage Publications.

7. European Commission Labour Market Latest Trends $2^{\text {nd }}$ quarter 2005 data

8. European Commission Report on equality between women and men 2005

9. National Statistical Service of Greece, Data concerning men and women

10. Petraki Kottis, A. and Ventoura Neokosmidi, Z., (2004), Women in Management in Greece, Women in Management Worldwide, Ashgate, England.

11. Petraki Kottis, A., (1991), Single European labour market: Equality between women and men, International Journal of Manpower, 12 (3), 3-8.

12. Petraki Kottis, A., (1996), Women in management and the glass ceiling in Greece, Women in Management 11 (2), 30-38.

13. Powell, G.N., (1999), Handbook of Gender and Work, Thousand Oaks, CA: Sage Publications.

14. Research Center for Gender Equality, Program for the Promotion of Gender Equality

15. Riger, P. and Galligan, S. (1980), Women in management: An exploration of Competing paradigms, American Psychologist, 35, 902-910.

16. Wirth, L., (2001), Breaking Through the Glass Ceiling - Women in Management, Geneva: International Labour Office.

\section{INTERNET SITES}

http://www.statistcs.gr

http://epp.eurostat.cec.eu.int

http://europa.eu.int

http://www.feminist.org

http://www.womenbusinessreasearch.org 